\title{
Long-term outcome of a child with hyperinsulinism- hyperammonaemia syndrome
}

\author{
HC Yau*, GWK Wong \\ From 7th APPES Biennial Scientific Meeting \\ Nusa Dua, Bali. 14-17 November 2012
}

\begin{abstract}
Aims
Clinical features of hyperinsulinism-hyperammonaemia syndrome are variable. A potential genotype-phenotype correlation of GLUD1 mutation and clinical features has been suggested. We here report the long-term outcome of a child with hyperinsulinism-hyperammonaemia syndrome.
\end{abstract}

\section{Methods}

A male infant was born at 38 gestational weeks with birth weight of $3.605 \mathrm{~kg}$. He presented with convulsion at 28 days of life. Physical examination was unremarkable. He was initially treated as meningoencephalitis. CT brain was unremarkable. Bacterial and viral cultures were negative. Plasma glucose upon admission was $1.2 \mathrm{mmol} / \mathrm{l}$ with negative urine ketone. Glucose infusion was high up to $12.1 \mathrm{mg} / \mathrm{kg} / \mathrm{min}$. Two sets of critical samples were obtained during hypoglycaemia.

Workup for metabolic diseases was unremarkable. But ammonia levels were persistently high up to 252$353 \mathrm{umol} / \mathrm{l}$. Octreotide injection was started to achieve euglycaemia. Protein free diet was tried but without success in lowering ammonia levels. Octreotide was later switched to oral diazoxide and hydrochlorothiazide. Full enteral feeding was established with stable glucose levels.

Table 1

\begin{tabular}{lll}
\hline Date & $\mathbf{2 8}$ days of life & $\mathbf{3 4}$ days of life \\
\hline Plasma glucose $(\mathbf{m m o l} / \mathrm{l})$ & 1.9 & 2.0 \\
\hline Insulin $(\mathrm{mlU} / \mathrm{l})$ & 23.9 & 10.5 \\
\hline Growth hormone $(\mathrm{IU} / \mathrm{l})$ & 54 & \\
\hline Cortisol $(\mathrm{nmol} / \mathrm{l})$ & 311 & \\
\hline
\end{tabular}

\section{Results}

Genetic analysis showed a mutation in axon 10; Asn410I1e (N410I), a mutation of AAC to ATC at codon 410. The diagnosis of hyperinsulinism-hyperammonaemia syndrome was confirmed. We follow the child until he is 6 years of age. Home blood glucose monitoring prevented him from hypoglycaemia. Fasting test was performed every year to fine tune his diazoxide dosage. He remained seizure free while ammonia levels remained high up to 123-218 $\mu \mathrm{mol} / \mathrm{l}$. Formal developmental assessment performed at 5 years of age showed delay in cognitive and speech development for 11.5 years, and attention-deficit hyperactivity syndrome.

\section{Conclusion}

Clinical features of hyperinsulinism-hyperammonaemia syndrome are variable. A genotype-phenotype correlation requires confirmation in larger series of patients.

Published: 3 October 2013

doi:10.1186/1687-9856-2013-S1-P182

Cite this article as: Yau and Wong: Long-term outcome of a child with hyperinsulinism- hyperammonaemia syndrome. International Journal of Pediatric Endocrinology 2013 2013(Suppl 1):P182. 